\title{
RELATIONSHIPS BETWEEN OCCUPATIONAL FUNCTIONING AND STRESS AMONG RADIO JOURNALISTS - ASSESSMENT BY MEANS OF THE PSYCHOSOCIAL RISK SCALE
}

\author{
ANNA NAJDER, DOROTA MERECZ-KOT, and ALEKSANDRA WÓJCIK \\ Nofer Institute of Occupational Medicine, Łódź, Poland \\ Department of Health and Work Psychology
}

\begin{abstract}
Objectives: Job characteristics and the consequences of everyday stress among radio journalists who are not exposed to traumatic events have not been studied sufficiently before. We aimed at determining the most common job characteristics and their stressfulness; relationships between stress exposure, health and occupational functioning; differences between radio journalists and other journalists, and also the psychosocial risk for health and functioning in this group. Material and Methods: The studied group involved 208 journalists, 134 of whom worked in radio stations. The respondents filled in the Psychosocial Risks Scale (PRS) developed by the Department of Health and Work Psychology of the Nofer Institute of Occupational Medicine, Łódź, Poland. Results: Requirement of mental effort and readiness to response quickly for most of the time as well as limited possibilities for promotion were the most frequent journalists' complaints. We confirmed that higher levels of stress resulted in worse functioning - the radio journalists who experienced lower stress assessed their health status and ability to work better, were more satisfied with particular aspects of their work, and were more involved in their work. They also presented a significantly lower turnover intention. Moreover, the radio journalists were more involved in their work than other journalists, but experienced lower satisfaction, took more sick leaves and had more days of absence. Conclusions: Well-known relationships between stress level, satisfaction and occupational functioning were confirmed. The most important conclusion refers to the fact that psychosocial risks and stress analysis should be based on the understanding of specificity of each occupation or even position. It is so, because the same job characteristic may pose a challenge for one person, while for another - it can result in extreme discomfort and anxiety - such an attitude broadens understanding of the phenomenon. We also confirmed that the PRS is a well-designed method, appropriate to investigate an individual perception of job environment and its stressfulness. Future research on causal relationships between the variables is recommended.
\end{abstract}

Key words:

Occupational stress, Radio journalists, Job content, Job context, Pathologies in relationships, Psychosocial risk factors

\section{INTRODUCTION}

Specific characteristics of a radio journalist's occupation Knowledge of specific characteristics of journalism might be derived from resources presenting subjective viewpoints (autobiographical books, non-reviewed articles). We did not find any systematic descriptions of a journalist's job based on demands and stressfulness analyses of this profession. According to the Polish Broadcasting Act of 1992 [1],

This work was supported by the European Union within the framework of European Social Found (grant number POKL.02.01.02-00-031/10). Grant manager: Maria Żytko, M.A.

Received: May 20, 2014. Accepted: April 13, 2015.

Corresponding author: A. Najder, Nofer Institute of Occupational Medicine, Department of Health and Work Psychology, św. Teresy 8, 91-348 Łódź, Poland (e-mail: anajder@imp.lodz.pl). 
media are in charge of 6 main tasks: providing information; making culture and art accessible; facilitating access to education, sport and science; promoting civic education; providing entertainment and supporting the national audiovisual production. By many, this occupation is found simple and pleasant. There is no formal classification of media professions. We cannot fully understand what kind of requirements a profession of a radio journalist involves and what this work looks like as far as work demands, stress and occupational functioning are concerned.

According to the latest job offers analyzed for the need of the study [2], editorial offices require primarily creativeness, ingenuity, self-reliance in research and editorial work. Besides, journalists are expected to respect deadlines, to have knowledge on word processors usage, correct spelling and pronunciation. What is just as important, journalists ought to be socially skilled so as to be able to work in teams. As mentioned in the "Guide to professions" (by the Polish Ministry of Economy), being a journalist requires dynamism and changeability of places where the work is performed, as well as various and frequent social contacts. However, work pace and topics vary depending on the type of a medium a journalist works for. Doing their job, journalists should be experts in selected life domains (e.g., politics, sport, medicine) and specialize in narrow sorts of journalistic job, like reportages or features. It is an individual job with a personal responsibility for its performance and quality [3]. In Poland, approximately $75 \%$ of people, on average, listen to the radio for $4 \mathrm{~h}$ and $25 \mathrm{~min}$ per day [4]. They are recipients of the news, debates, reports, competitions and, obviously, music. It makes them likely to believe that radio journalists' work is pleasant, stress-free and at least satisfactory as it is associated with providing entertainment. In public opinion they seem to do rather a white-collar job, working inside a quiet recording studio, mostly deprived of stressful situations.

Professions that are socially useful but highly demanding and, thus, stressful (e.g., uniform and medical services, teachers) have been widely investigated. Everyday occupational stress in professions assumed as not demanding (like in the case of radio journalists) may be underestimated and result in health and occupational functioning consequences.

\section{Job characteristics, stressors and psychosocial risks}

Occupational stress has been explored for years. What is relatively new is the current approach considering psychosocial risks at work also as an interaction between work environment and an individual [5]. According to the above, it is emphasized that the occurrence of psychosocial risks itself does not necessarily mean harm or damage to an employee's well-being. What is significant, is whether the job characteristic causes stress, because then it can become a risk for further consequences.

Each psychosocial job characteristic may influence an employee's health and functioning. Such an influence may be positive (e.g., interpersonal relationships are a source of social support) or negative, because each job characteristic may be of stressful nature (e.g., relationships also constitute a source of conflicts). When a job characteristic is perceived as stressful, it may turn into a stressor and become a psychosocial risk - such an aspect of work design, management or social context that potentially causes psychological or physical harm [6]. Psychosocial risks influence individuals through psychophysiological stress mechanisms [7] and might be considered as universal they occur in most workplaces regardless of a specific job nature or position. Depending on a branch of industry, occupation or position, the so called "branch specific risks" should be also considered. All of the above are considered in a new questionnaire designed by the psychologists from the Nofer Institute of Occupational Medicine, Łódź, Poland - the Psychosocial Risk Scale (PRS).

Occupational environment of journalists is well-recognized in terms of symptoms and styles of coping with posttraumatic stress among "field reporters" dealing with 
extreme incidents. However, stressful job characteristics as well as occupational functioning of radio journalists who are not exposed to traumatic events in their everyday work, have not been studied sufficiently before.

\section{Aims}

The study aimed at exploring characteristics of radio journalism as a profession. We wanted to answer the following research questions:

- Which job characteristics are the most common among radio journalists and which of them are stressful?

- Are there any relationships between stress, health and occupational functioning in this group?

- Are there any differences between radio journalists and journalists working in other media concerning stress and its consequences?

- Is a radio journalist's job related to a psychosocial risk for health and functioning?

\section{MATERIAL AND METHODS}

\section{Procedure}

An anonymous survey was conducted in Polish private enterprises within the framework of a nationwide research project. Purposive sample selection was used to collect data from 15 various branches of industry. Interviewers delivered the questionnaires to the respondents who filled them in individually. Only completed questionnaires were accepted (excluding questions about pathologies in the workplace - the respondents could leave these questions unanswered). To develop the Psychosocial Risks Scale (PRS) used in the study, the authors [8] made use of the typology of risks and assumptions worked out by the European Union experts within the Psychosocial Risk Management Excellence Framework (PRIMA-EF) [6].

\section{Sample}

From the sample of 7624 respondents representing different occupational groups, 208 journalists were extracted, 134 of whom were hired in radio stations. The rest of them were established as "other journalists." Women constituted $55.2 \%$ of all the radio journalists. Their mean age was nearly 35 years old. The investigated journalists have worked in the current position, on average, for 11.4 years, and 6.6 years. Among all the radio journalists, $98.5 \%$ of the participants had higher education.

\section{Method}

The questionnaire included:

- Parts A and B - demographic data and information on absenteeism, self-assessed health and work ability, job satisfaction with various aspects of work, job involvement or a turnover intention.

- Part C - a 50-item questionnaire concerning job characteristics appropriate for most employees, irrespectively of their workplace and occupation or profession divided into 3 subscales: Job Content, Job Context and Pathologies in Relationships. Psychometric properties of the scale were appraised on the basis of 7623 surveyed respondents. Internal consistency coefficient Cronbach's $\alpha$ for the entire scale amounted to 0.94 .

- Part D (branch annex) - questions designed for employees of a particular branch of the industry.

The journalists were classified as employees of a culture branch. Annex for these workers consists of 14 statements which form the 4th subscale - the Branch Specific. Cronbach's $\alpha$ for this scale amounted to 0.80 [8].

The respondents assessed whether a particular job characteristic (listed in parts $\mathrm{C}$ and D) occurred in their workplace ("yes" or "no") and if it did - to what extent they were stressed because of it, using a 3-degree scale ("it does not stress me out," "it makes me a little stressed," "it makes me very stressed").

Therefore, we received 2 sorts of data concerning the occurrence of given psychosocial work characteristics and 
their stressfulness. The occurrence was estimated by counting how many job characteristics occurred in a respondent's workplace (regardless of its stressfulness). It means that all occurring characteristics in one's workplace were added all together.

To establish an indicator of stressfulness, we counted the sum of all occurring characteristics that were found stressful (regardless of the level of stressfulness, including: "it makes me a little stressed," "it makes me very stressed").

The data were analyzed by the use of the Spearman's ranks correlations and the Mann-Whitney U test.

\section{RESULTS}

\section{Job characteristics}

Table 1 presents means and standard deviations for the variables under the study among the radio and other journalists.

Tables 2-5 present the core part of the research involving characteristics of the occurrence and stressfulness of psychosocial risks in a radio journalist's work environment divided into 4 types of stressors: Job Content, Job Context, Pathologies in Relationships and Branch Specific job characteristics. From the Job Content stressors, readiness to response quickly, the need for prolonged attention and availability

Table 1. Descriptive statistics of the radio and other journalists

\begin{tabular}{|c|c|c|}
\hline Variable & $\begin{array}{l}\text { Radio journalists } \\
\qquad \begin{array}{c}(\mathrm{N}=134) \\
(\mathrm{M} \pm \mathrm{SD})\end{array}\end{array}$ & $\begin{array}{l}\text { Other journalists } \\
\qquad \begin{array}{l}(\mathrm{N}=74) \\
(\mathrm{M} \pm \mathrm{SD})\end{array}\end{array}$ \\
\hline Age [years] & $34.73 \pm 6.45$ & $38.54 \pm 9.12$ \\
\hline Sick leaves [n] & $0.58 \pm 0.97$ & $0.22 \pm 0.48$ \\
\hline Absence [days] & $4.67 \pm 10.89$ & $2.11 \pm 4.44$ \\
\hline Self-assessed health status & $4.31 \pm 0.70$ & $4.32 \pm 0.85$ \\
\hline Self-assessed ability to work & $4.25 \pm 0.62$ & $4.19 \pm 0.66$ \\
\hline Work involvement & $4.46 \pm 0.64$ & $4.23 \pm 0.65$ \\
\hline \multicolumn{3}{|l|}{ Satisfaction with: } \\
\hline type of work & $3.37 \pm 0.51$ & $3.45 \pm 0.62$ \\
\hline organization of work & $2.93 \pm 0.68$ & $3.15 \pm 0.79$ \\
\hline working conditions & $3.07 \pm 0.64$ & $3.27 \pm 0.67$ \\
\hline salary and benefits & $2.78 \pm 0.79$ & $2.92 \pm 0.95$ \\
\hline career development & $2.94 \pm 0.81$ & $3.15 \pm 0.89$ \\
\hline the relationship with superior & $3.18 \pm 0.67$ & $3.50 \pm 0.69$ \\
\hline the relationship with colleagues & $3.34 \pm 0.67$ & $3.66 \pm 0.50$ \\
\hline Turnover intention ${ }^{\mathrm{a}}$ & $3.32 \pm 0.86$ & $3.35 \pm 0.91$ \\
\hline \multicolumn{3}{|l|}{ Occurrence of: } \\
\hline Job Context & $8.57 \pm 6.78$ & $9.03 \pm 5.66$ \\
\hline Job Content & $8.26 \pm 2.85$ & $10.18 \pm 2.12$ \\
\hline Pathologies in Relationships & $0.30 \pm 0.86$ & $0.31 \pm 0.91$ \\
\hline Branch Specific job characteristics & $1.82 \pm 2.46$ & $3.51 \pm 2.90$ \\
\hline
\end{tabular}


Table 1. Descriptive statistics of the radio and other journalists - cont.

\begin{tabular}{lcc}
\hline \multicolumn{1}{c}{ Variable } & $\begin{array}{c}\text { Radio journalists } \\
(\mathrm{N}=134)\end{array}$ & $\begin{array}{c}\text { Other journalists } \\
(\mathrm{N}=74) \\
(\mathrm{M} \pm \mathrm{SD})\end{array}$ \\
\hline $\begin{array}{l}\text { Stressfulness of: } \\
\text { Job Context }\end{array}$ & & \\
Job Content & $7.68 \pm 6.49$ & $6.92 \pm 5.81$ \\
Pathologies in Relationships & $6.04 \pm 3.62$ & $6.27 \pm 4.38$ \\
Branch Specific job characteristics & $0.27 \pm 0.84$ & $0.22 \pm 0.73$ \\
Stress (total) & $5.41 \pm 3.48$ & $6.24 \pm 3.80$ \\
\hline
\end{tabular}

${ }^{a}$ The higher the score, the lower the turnover intention.

$\mathrm{M}$ - mean; SD - standard deviation.

Table 2. The occurrence and stressfulness of the Job Content characteristics

\begin{tabular}{|c|c|c|c|}
\hline \multirow[b]{2}{*}{ Job Content item } & \multicolumn{3}{|c|}{$\begin{array}{l}\text { Respondents } \\
(\mathrm{N}=134)\end{array}$} \\
\hline & $\begin{array}{c}\text { indicating given job } \\
\text { characteristic } \\
{[\mathrm{n}(\%)]}\end{array}$ & $\begin{array}{c}\text { indicating stress } \\
\text { caused by the given } \\
\text { job characteristic } \\
{[\mathrm{n}(\%)]}\end{array}$ & $\begin{array}{c}\text { stressed } \\
\text { (in the whole radio } \\
\text { journalists group) } \\
{[\%]}\end{array}$ \\
\hline My job, for most of the time, requires readiness to response quickly & $125(93)$ & $92(74)$ & 69 \\
\hline My job requires prolonged attention & $124(93)$ & $92(74)$ & 69 \\
\hline My job requires using new technologies & $119(89)$ & $77(65)$ & 58 \\
\hline Availability is required in my job & $118(88)$ & $92(78)$ & 69 \\
\hline My job requires continuous upskilling & $91(68)$ & $52(57)$ & 39 \\
\hline $\begin{array}{l}\text { In my job, I must switch from one activity to another and each } \\
\text { of them requires some attention }\end{array}$ & $87(65)$ & $74(85)$ & 55 \\
\hline The job I perform is below my qualifications & $78(58)$ & $56(72)$ & 42 \\
\hline $\begin{array}{l}\text { My job performance and its quality depend on whether and how } \\
\text { my predecessors did it earlier }\end{array}$ & $73(55)$ & $53(72)$ & 40 \\
\hline My superior often controls what and how I work & $63(47)$ & $47(75)$ & 35 \\
\hline $\begin{array}{l}\text { In my job, team (group) responsibility for the performance } \\
\text { and quality of work is applied }\end{array}$ & $55(41)$ & $43(78)$ & 32 \\
\hline There is employees' evaluation system in my work & $46(34)$ & $34(74)$ & 25 \\
\hline In my job, I often have to make decisions that cause inner conflicts & $45(34)$ & $39(87)$ & 29 \\
\hline $\begin{array}{l}\text { My work is often controlled (internal and external audits, } \\
\text { inspections, quality control etc.) }\end{array}$ & $42(31)$ & $35(83)$ & 26 \\
\hline In my position, the way of performing the job changes a lot & $41(31)$ & $24(59)$ & 18 \\
\hline
\end{tabular}


Table 3. The occurrence and stressfulness of the Job Context characteristics

\begin{tabular}{|c|c|c|c|}
\hline \multirow[b]{2}{*}{ Job Context item } & \multicolumn{3}{|c|}{$\begin{array}{l}\text { Respondents } \\
(\mathrm{N}=134)\end{array}$} \\
\hline & $\begin{array}{l}\text { indicating given job } \\
\text { characteristic } \\
{[\mathrm{n}(\%)]}\end{array}$ & $\begin{array}{c}\text { indicating stress } \\
\text { caused by the given } \\
\text { job characteristic } \\
{[\mathrm{n}(\%)]}\end{array}$ & $\begin{array}{c}\text { stressed } \\
\text { (in the whole radio } \\
\text { journalists group) } \\
{[\%]}\end{array}$ \\
\hline Possibilities for promotion are limited in my job & $85(63)$ & $78(92)$ & 58 \\
\hline $\begin{array}{l}\text { Work organization in my company hinders the possibility to plan } \\
\text { the next day (what I should do that day) }\end{array}$ & $70(52)$ & $62(89)$ & 46 \\
\hline $\begin{array}{l}\text { Rules of giving bonuses and remunerations are ambiguous } \\
\text { in my company }\end{array}$ & $66(49)$ & $62(94)$ & 46 \\
\hline $\begin{array}{l}\text { Due to the nature of my job, I must resign from many previously } \\
\text { planned private issues }\end{array}$ & $65(49)$ & $63(97)$ & 47 \\
\hline $\begin{array}{l}\text { In my company, employees' participation in making decisions } \\
\text { concerning our organization's operation is very limited }\end{array}$ & $61(46)$ & $50(82)$ & 37 \\
\hline There is a threat of dismissals in my work & $57(43)$ & $52(91)$ & 39 \\
\hline My job influences my private life in a negative way & $56(42)$ & $55(98)$ & 41 \\
\hline I have too many duties in my job & $54(40)$ & $46(85)$ & 34 \\
\hline $\begin{array}{l}\text { In my job, I often face obstacles hindering the possibility to meet } \\
\text { the deadlines }\end{array}$ & $52(39)$ & $48(92)$ & 36 \\
\hline My company is indifferent to employees' initiatives & $52(39)$ & $48(92)$ & 36 \\
\hline $\begin{array}{l}\text { The possibilities to gain/improve qualifications are insufficient } \\
\text { in my company }\end{array}$ & $51(38)$ & $44(86)$ & 33 \\
\hline $\begin{array}{l}\text { In my position, the necessary changes in the way of performing job } \\
\text { are rarely introduced }\end{array}$ & $49(37)$ & $37(76)$ & 28 \\
\hline $\begin{array}{l}\text { In my company, employees are not informed of current goals of } \\
\text { the company's policy }\end{array}$ & $45(34)$ & $43(96)$ & 32 \\
\hline $\begin{array}{l}\text { Social benefits and bonuses in my company (such as organizing } \\
\text { summer trips, passes/tickets for swimming pools, gym, cinema, } \\
\text { theatre) are not adjusted to my needs }\end{array}$ & $42(31)$ & $40(95)$ & 30 \\
\hline There is tense atmosphere in my workplace & $38(28)$ & $33(87)$ & 25 \\
\hline I lack feedback on the quality of my work & $35(26)$ & $31(89)$ & 23 \\
\hline My job lacks procedures of performing tasks & $32(24)$ & $29(91)$ & 22 \\
\hline $\begin{array}{l}\text { I have limited access to information concerning my functioning } \\
\text { in the company (organizational issues) }\end{array}$ & $29(22)$ & $25(86)$ & 19 \\
\hline $\begin{array}{l}\text { Arguments, conflicts or disagreements among employees are } \\
\text { common in my company }\end{array}$ & $28(21)$ & $27(96)$ & 20 \\
\hline $\begin{array}{l}\text { I have limited access to information necessary to perform my job } \\
\text { (such as instructions or guidelines) }\end{array}$ & $25(19)$ & $25(100)$ & 19 \\
\hline It is hard to communicate with my direct supervisor & $25(19)$ & $20(80)$ & 15 \\
\hline
\end{tabular}


Table 3. The occurrence and stressfulness of the Job Context characteristics - cont.

\begin{tabular}{|c|c|c|c|}
\hline \multirow[b]{2}{*}{ Job Context item } & \multicolumn{3}{|c|}{$\begin{array}{l}\text { Respondents } \\
(\mathrm{N}=134)\end{array}$} \\
\hline & $\begin{array}{l}\text { indicating given job } \\
\text { characteristic } \\
{[\mathrm{n}(\%)]}\end{array}$ & $\begin{array}{c}\text { indicating stress } \\
\text { caused by the given } \\
\text { job characteristic } \\
{[\mathrm{n}(\%)]}\end{array}$ & $\begin{array}{c}\text { stressed } \\
\text { (in the whole radio } \\
\text { journalists group) } \\
{[\%]}\end{array}$ \\
\hline It is not clear what is expected from me in my job & $24(18)$ & $21(88)$ & 16 \\
\hline $\begin{array}{l}\text { In my company there are problems with getting help from my } \\
\text { superior }\end{array}$ & $23(17)$ & $20(87)$ & 15 \\
\hline $\begin{array}{l}\text { I often have to perform my job despite the lack of suitable means } \\
\text { (e.g., tools or materials) }\end{array}$ & $23(17)$ & $18(78)$ & 13 \\
\hline My job requires complying with strictly specified procedures & $21(16)$ & $18(86)$ & 13 \\
\hline $\begin{array}{l}\text { In my company there are problems with getting help from my } \\
\text { colleagues }\end{array}$ & $20(15)$ & $17(85)$ & 13 \\
\hline $\begin{array}{l}\text { In my job, there is the lack of access to modern technological } \\
\text { solutions }\end{array}$ & $15(11)$ & $13(87)$ & 10 \\
\hline I work in particularly difficult physical conditions & $5(4)$ & $4(80)$ & 3 \\
\hline
\end{tabular}

Table 4. The occurrence and stressfulness of the Pathologies in Relationships job characteristics

\begin{tabular}{lccc}
\hline \multicolumn{1}{c}{ Pathologies in Relationships item } & \multicolumn{3}{c}{$\begin{array}{c}\text { Respondents } \\
\text { (N = 134) }\end{array}$} \\
\cline { 2 - 4 } & $\begin{array}{c}\text { indicating the given } \\
\text { job characteristic } \\
{[\mathrm{n}(\%)]}\end{array}$ & $\begin{array}{c}\text { indicating stress } \\
\text { caused by the given } \\
\text { job characteristic } \\
{[\mathrm{n}(\%)]}\end{array}$ & $\begin{array}{c}\text { stressed } \\
\text { journalists group) } \\
{[\%]}\end{array}$ \\
\hline $\begin{array}{l}\text { In my work I am exposed to psychological aggression from my } \\
\text { colleagues and superiors (shouts, verbal insults, blackmail, } \\
\text { threats etc.) }\end{array}$ & $15(11)$ & $13(87)$ & 10 \\
$\begin{array}{l}\text { In my company there are mobbing incidents (systematic } \\
\text { harassment, bullying lasting at least 3 months) }\end{array}$ & $10(8)$ & $10(100)$ & 4 \\
$\begin{array}{l}\text { There are discrimination incidents in my company (e.g., because } \\
\text { of my gender, age, denomination, party affiliation, political } \\
\text { views, nationality, race, sexual orientation, health status, family } \\
\text { situation) }\end{array}$ & $5(4)$ & $5(100)$ & 4 \\
$\begin{array}{l}\text { I am discriminated in my work (because of, for example, my gender, } \\
\text { age, denomination, party affiliation, political views, nationality, } \\
\text { race, sexual orientation, health status, family situation) }\end{array}$ & $5(4)$ & $5(100)$ & 2 \\
$\begin{array}{l}\text { In my work, I am mobbed (systematically harassed, bullied for at } \\
\text { least 3 months) }\end{array}$ & $3(2)$ & $3(100)$ & \\
\begin{tabular}{l} 
In my company there are sexual harassment incidents \\
\hline
\end{tabular} & $1(1)$ & $0(0)$ & 0 \\
\hline
\end{tabular}


Table 4. The occurrence and stressfulness of the Pathologies in Relationships job characteristics - cont.

\begin{tabular}{lccc}
\hline \multirow{2}{*}{ Pathologies in Relationships item } & \multicolumn{3}{c}{$\begin{array}{c}\text { Respondents } \\
\text { (N = 134) }\end{array}$} \\
\cline { 2 - 4 } & $\begin{array}{c}\text { indicating the given } \\
\text { job characteristic } \\
{[\mathrm{n}(\%)]}\end{array}$ & $\begin{array}{c}\text { indicating stress } \\
\text { caused by the given } \\
\text { job characteristic } \\
{[\mathrm{n}(\%)]}\end{array}$ & $\begin{array}{c}\text { stressed } \\
\text { journalists group) } \\
{[\%]}\end{array}$ \\
\hline $\begin{array}{l}\text { I am sexually harassed in my work } \\
\begin{array}{l}\text { In my job, I am exposed to physical aggression from my colleagues } \\
\text { or superiors (beating, pushing, pulling, using dangerous tools) }\end{array}\end{array}$ & $1(1)$ & $0(0)$ & 0 \\
\hline
\end{tabular}

Table 5. The occurrence and stressfulness of the Branch Specific job characteristics

\begin{tabular}{|c|c|c|c|}
\hline \multirow[b]{2}{*}{ Branch Specific item } & \multicolumn{3}{|c|}{$\begin{array}{l}\text { Respondents } \\
(\mathrm{N}=134)\end{array}$} \\
\hline & $\begin{array}{l}\text { indicating the given } \\
\text { job characteristic } \\
{[\mathrm{n}(\%)]}\end{array}$ & $\begin{array}{l}\text { indicating stress } \\
\text { caused by the given } \\
\text { job characteristic } \\
{[\mathrm{n}(\%)]}\end{array}$ & $\begin{array}{c}\text { stressed } \\
\text { (in the whole radio } \\
\text { journalists group) } \\
{[\%]}\end{array}$ \\
\hline My job requires a lot of mental effort & $128(96)$ & $84(66)$ & 63 \\
\hline My job is emotionally charging & $114(85)$ & $104(94)$ & 78 \\
\hline $\begin{array}{l}\text { My job involves helping/rendering services/providing information } \\
\text { to other people }\end{array}$ & $105(78)$ & $62(59)$ & 46 \\
\hline My job requires close teamwork. & $96(72)$ & $60(63)$ & 45 \\
\hline $\begin{array}{l}\text { Due to the nature of my job, I usually cannot predict what will } \\
\text { happen that day (out in the field intervention, call to breakdown, } \\
\text { duty, etc.) }\end{array}$ & $85(63)$ & $67(79)$ & 50 \\
\hline $\begin{array}{l}\text { In my job, I must do a lot of work in a short period of time } \\
\text { (I have fixed deadlines for performing some of my duties) }\end{array}$ & $80(60)$ & $64(80)$ & 48 \\
\hline I can expect extreme and unpredictable human reactions in my job & $75(56)$ & $55(73)$ & 41 \\
\hline There is a competition and rivalry in my job & $72(54)$ & $60(83)$ & 45 \\
\hline My job requires attendance in places of extreme events & $66(49)$ & $43(54)$ & 32 \\
\hline In my job, I often have to work extra hours & $53(40)$ & $49(93)$ & 37 \\
\hline $\begin{array}{l}\text { My job performance and quality depend on the quality } \\
\text { of the relationships with recipients/customers }\end{array}$ & $49(37)$ & $39(80)$ & 29 \\
\hline $\begin{array}{l}\text { In my job I am exposed to psychological aggression from my } \\
\text { colleagues and superiors (shouts, verbal insults, blackmail, } \\
\text { threats etc.) }\end{array}$ & $25(19)$ & $24(96)$ & 18 \\
\hline My job requires a lot of physical effort & $14(10)$ & $9(64)$ & 7 \\
\hline $\begin{array}{l}\text { In my job, I am exposed to physical aggression from my colleagues } \\
\text { or superiors (beating, pushing, pulling, using dangerous tools) }\end{array}$ & $7(5)$ & $5(71)$ & 4 \\
\hline
\end{tabular}


turned out to be stressful for the greatest number of all the respondents and caused stress among $68.7 \%$ of them (Table 2).

Among the Job Context characteristics, 2 were experienced by more than $1 / 2$ of the respondents - the limited possibilities for promotion as well as work organization hindering the possibility to plan the following working day. All the occurring job characteristics were stressful to at least $75 \%$ of the respondents who experienced them (Table 3).

Job characteristics concerning Pathologies in Relationships in comparison to the other subscales were experienced relatively rarely among the radio journalists. But once they did occur, they were stressful for the majority of the respondents who indicated them or, even more usually, for all of them (Table 4). The most common incident was psychological aggression from colleagues or superiors $-11.2 \%$ of the interviewed individuals reported such behaviors. At the same time, it was stressful to $86.7 \%$ of them. Nevertheless, it constituted no more than $10 \%$ of all the respondents.

Twenty radio journalists $(14.9 \%)$ declared that at least 1 job characteristic showing features of pathology in interpersonal relationships occurred in their workplace. Among these cases, $50 \%$ of the individuals answered that incidents of bullying happened in their company $(7.5 \%$ of the sample). Another $15 \%$ of this group (2.2\%) declared they had fallen a victim to bullying. The experience of discrimination was declared by $3.4 \%$ of the radio journalists and the same number of them noticed the acts of discrimination in their companies (concerning other individuals). Sexual harassment concerned $1.5 \%$ of the individuals who took part in the research, while half of them experienced sexual harassment and the 2 nd half reported that the cases of sexual harassment had taken place in their company. No one from the sample was in danger of physical aggression, but 10 journalists $-8 \%$ of the participants declared they were exposed to psychological aggression from co-workers or superiors. It was the most frequent pathological behavior among the radio journalists.

The majority of the Branch Specific job characteristics listed in the questionnaire occurred in at least $50 \%$ of the radio journalists (Table 5). The greatest stressfulness related to psychological aggression, working extra hours and the job being emotionally charging.

Table 6 presents the correlations between the main variables under the study reflecting the radio journalists' functioning at work.

Basing on medians, we divided the respondents into 2 subgroups depending on their level of stress caused by each type of job characteristics (subscale) - low stress and high stress groups. The results suggest that people with a lower stress level functioned better at work - they assessed their health and ability to work better, they were more involved in work and more satisfied with the majority of aspects of their work. Also their intention to change the job was lower than among those who experienced more stress. Most often these were the Job Context Subscale and the Stress in Total that differentiated functioning of the respondents with low and high stress (Table 7). In the presented comparisons the Pathologies in Relationships Subscale was excluded because of a relatively low number of the respondents who experienced such pathologies $(\mathrm{N}=30)$.

Further, we compared the occurrence and stressfulness of given job characteristics and the variables indicating functioning at work between the radio and other journalists. The Mann-Whitney $\mathrm{U}$ analysis revealed that the radio journalists were significantly younger than the journalists working in other media (mean age of the radio journalists being 34.7 and of others $-38.5, Z=-3.11, p<0.01$ ), and their job tenure was significantly shorter (both total and in the current position). There were no significant differences between the radio and other journalists considering their sex. Other journalists reported more Job Content and Branch Specific potential job stressors in their workplace 


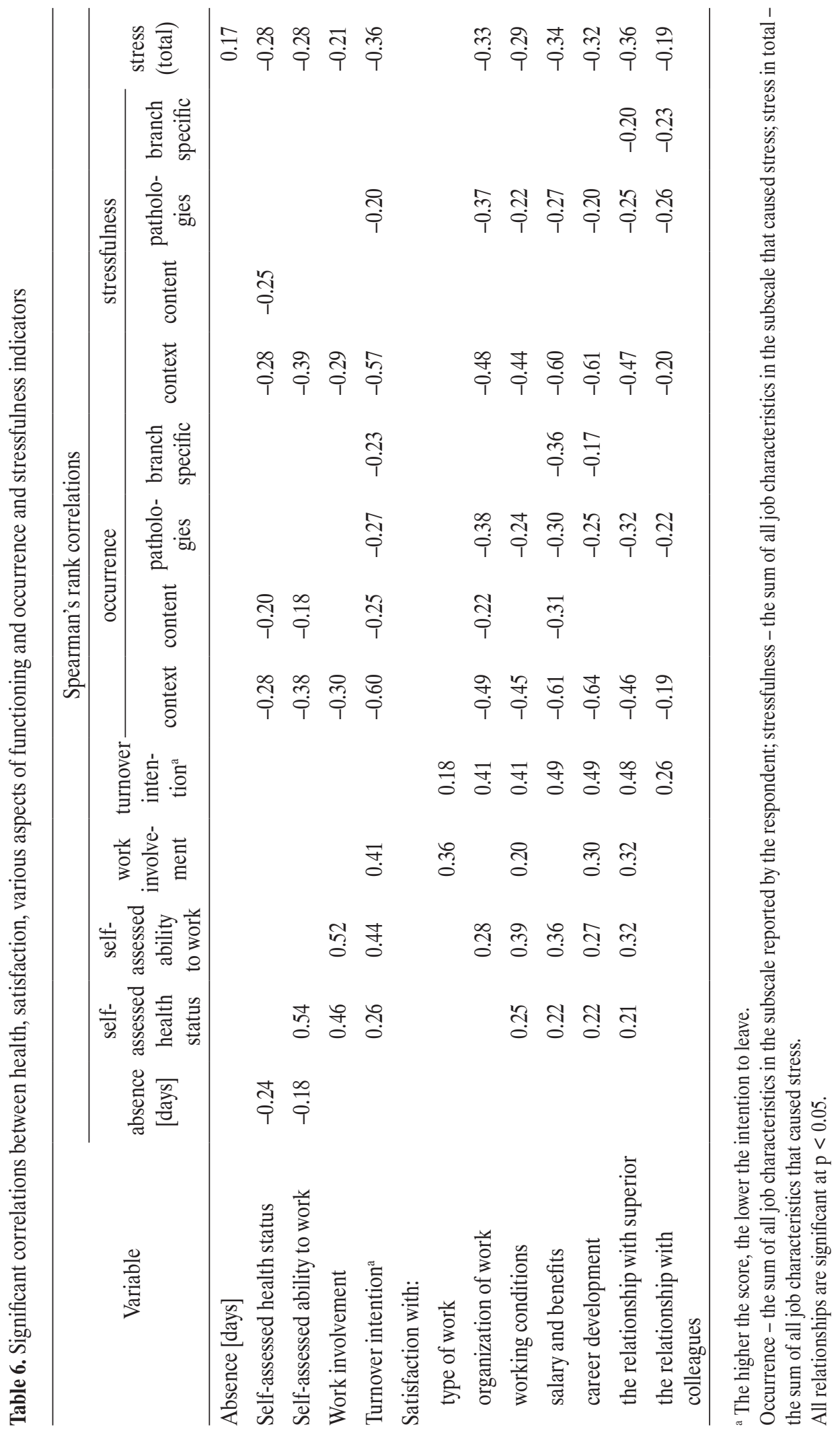


Table 7. Significant differences in the consequences between low stress and high stress caused by each job characteristics type (the Mann-Whitney U test results)

\begin{tabular}{|c|c|c|c|c|c|c|}
\hline \multirow{2}{*}{ Dependant variable } & \multirow{2}{*}{ Grouping variable } & \multicolumn{2}{|c|}{ Journalists with low stress } & \multicolumn{2}{|c|}{ Journalists with high stress } & \multirow{2}{*}{$\mathrm{Z}$} \\
\hline & & $\mathrm{n}$ & M & $\mathrm{n}$ & M & \\
\hline \multicolumn{7}{|l|}{ Self-assessed health status } \\
\hline & Job Context stress & 74 & 74.25 & 60 & 59.18 & $-2.445^{*}$ \\
\hline & Job Content stress & 69 & 73.70 & 65 & 60.92 & $-2.085^{*}$ \\
\hline & total stress & 68 & 76.35 & 66 & 58.38 & $-2.931 * *$ \\
\hline \multicolumn{7}{|l|}{ Self-assessed ability to work } \\
\hline & Job Context stress & 74 & 78.65 & 60 & 53.75 & $-4.171^{* * *}$ \\
\hline & total stress & 68 & 77.53 & 66 & 57.17 & $-3.429 * *$ \\
\hline \multicolumn{7}{|l|}{ Work involvement } \\
\hline & Job Context stress & 74 & 76.05 & 60 & 56.96 & $-3.186 * *$ \\
\hline & total stress & 68 & 75.43 & 66 & 59.33 & $-2.700 * *$ \\
\hline \multirow{2}{*}{\multicolumn{7}{|c|}{$\begin{array}{l}\text { Satisfaction with: } \\
\text { organization of work }\end{array}$}} \\
\hline & & & & & & \\
\hline & Job Context stress & 74 & 82.65 & 60 & 48.82 & $-5.881 * * *$ \\
\hline & total stress & 68 & 73.32 & 66 & 61.51 & $-2.064^{*}$ \\
\hline \multicolumn{7}{|l|}{ working conditions } \\
\hline & Job Context stress & 74 & 79.27 & 60 & 52.98 & $-4.405^{* * *}$ \\
\hline & total stress & 68 & 74.44 & 66 & 60.35 & $-2.374 *$ \\
\hline \multicolumn{7}{|l|}{ salary and benefits } \\
\hline & Job Context & 74 & 83.77 & 60 & 47.43 & $-5.804 * * *$ \\
\hline & total stress & & 77.54 & & 57.15 & $-3.275^{* *}$ \\
\hline \multicolumn{7}{|l|}{ career development } \\
\hline & Job Context stress & 74 & 83.23 & 60 & 48.10 & $-5.605^{* * *}$ \\
\hline & Total stress & 68 & 76.72 & 66 & 58.00 & $-3.003^{* *}$ \\
\hline \multicolumn{7}{|l|}{ relationship with colleagues } \\
\hline & Branch Specific stress & 77 & 73.23 & 57 & 59.75 & $-2.230^{*}$ \\
\hline \multicolumn{7}{|l|}{ relationship with a superior } \\
\hline & Job Context stress & 74 & 77.81 & 60 & 54.78 & $-3.852^{* * *}$ \\
\hline & total stress & 68 & 75.53 & 66 & 59.23 & $-2.741 * *$ \\
\hline \multicolumn{7}{|l|}{ Turnover intention ${ }^{\mathrm{a}}$} \\
\hline & Job Context stress & 74 & 84.35 & 60 & 46.72 & $-5.981^{* * *}$ \\
\hline & total stress & 68 & 78.46 & 66 & 56.21 & $-3.554^{* * *}$ \\
\hline
\end{tabular}

a The higher the mean, the lower the intention to leave.

$\mathrm{M}-$ mean.

${ }^{*} \mathrm{p}<0.05 ;{ }^{* *} \mathrm{p}<0.01 ;{ }^{* * *} \mathrm{p}<0.001$. 
Table 8. Significant differences between the radio and other journalists (the Mann-Whitney U test results)

\begin{tabular}{lccc}
\hline \multicolumn{1}{c}{ Variable } & $\begin{array}{c}\text { Radio journalists } \\
(\mathrm{N}=134) \\
(\mathrm{M})\end{array}$ & $\begin{array}{c}\text { Other journalists } \\
(\mathrm{N}=74) \\
(\mathrm{M})\end{array}$ & $\mathrm{Z}$ \\
\hline Occurrence of the Job Content & 88.21 & 134.01 & $-5.300^{* * *}$ \\
Occurrence of the Branch Specific job characteristics & 91.05 & 128.85 & $-4.487^{* * *}$ \\
Work involvement & 111.49 & 91.84 & $-2.500^{*}$ \\
Satisfaction with: & & & \\
$\quad$ organization of work & 98.30 & 115.73 & $-2.242^{*}$ \\
working conditions & 98.39 & 115.57 & $-2.212^{*}$ \\
$\quad$ relationship with a superior & 94.38 & 122.82 & $-3.609^{* * *}$ \\
$\quad$ relationship with colleagues & 94.98 & 121.74 & $-3.477^{* *}$ \\
Sick leaves [n] & 111.44 & 91.93 & $-2.784^{* *}$ \\
Absence [days] & 110.37 & 93.86 & $-2.196^{*}$ \\
\hline
\end{tabular}

Occurrence - the sum of all job characteristics in the subscale reported by the respondent.

$\mathrm{M}-$ mean.

$* \mathrm{p}<0.05 ; * \mathrm{p}<0.01 ; * * * \mathrm{p}<0.001$.

than the radio journalists did (Table 8). Considering their functioning at work, the radio journalists were significantly more involved but at the same time, they were less satisfied with the organization of work, working conditions, relationships with a superior and colleagues. The radio journalists took more sick leaves and they had more days of absence (during the 12 months preceding the study). At least 1 sick leave was taken by $35.8 \%$ of them (during the 12 months preceding the study).

\section{DISCUSSION}

The study aimed at exploring characteristics of radio journalism as a profession. In our research, majority of the radio journalists indicated the requirement of mental effort, readiness to response quickly for most of the time and limited possibilities for promotion as characteristics of their work. At the same time, the greatest number of radio journalists found emotional charge, requirement of availability, the need for prolonged attention and readiness to react quickly the most stressful. Our findings revealed the need for separating job demands occurrence from their stressfulness. It means that the most frequently occurring psychosocial risks are not necessarily the most stressful for all the employees. Therefore, we assume that the PRS is a well-designed method, appropriate to investigate an individual perception of job environment and its stressfulness.

We distinguished differences between the low and high stressed employees as regards health and occupational functioning. Generally, higher levels of stress resulted in worse functioning at work, regardless of the type of job characteristics causing the stress. The radio journalists who experienced lower total stress and stress caused by job context assessed their health status and ability to work better, they were more satisfied with particular aspects of their work and were more involved. The employees who experienced a higher stress level also presented a significantly higher turnover intention. This corresponds to a previous research revealing that ambiguous rules, limited possibilities for promotion, lack of control and conditions that support work-family conflict are only a few features which are well known to worsen employees' functioning 
in organizations [9-12]. Moreover, the radio journalists who were more stressed by branch specific stressors were also less satisfied with their colleagues than those who experienced lower levels of such stressors. We also found that stress caused by job content differentiated the radio journalists as far as their self-assessed health status was considered.

The above-mentioned findings indicate that diverse stressors (e.g., job content, context or branch specific) lead to different health and occupational consequences, e.g., among the groups of high versus low stress. Therefore, it is important for specialists responsible for psychosocial risks assessment in organizations to be open to diagnosis reflecting the occurrence and stressfulness separately.

Pathologies in relationships in comparison to other stressors were experienced relatively rarely among the radio journalists. But once they occurred, they were stressful for the majority or all the respondents who experienced them at work. We revealed that stressfulness of pathologies in relationships in the workplace did not differentiate neither health, satisfaction nor occupational functioning but, at the same time, they were significantly correlated with all aspects of satisfaction. It means that even a low level of stress caused by pathological behaviors of co-workers and/or superiors was associated with lower job satisfaction. The occurrence of any acts of pathology, regardless of whether it happens to the employee or to his/her colleagues, results in negative consequences to his or her well-being. This outcome is a clear clue for employers that they are obligated to create bullying- and discriminationfree work environments.

We also found some significant differences between the radio and other journalists (working in newspapers, television) in terms of stress and its consequences. The radio journalists were more involved in their work than other journalists, but experienced lower satisfaction with organization of work, working conditions and relationships with superiors and colleagues, they took more sick leaves and had more days of absence from work. They also experienced less branch specific and job content characteristics in their workplace.

The radio journalists could have expressed lower satisfaction because they were significantly younger and had shorter job tenure than their counterparts from other media. As the research and meta-analytic reviews indicate, age and job tenure correlate positively with job satisfaction [13-17]. It means that the older an employee, the more satisfied he or she is. It could be explained with differences in needs and expectations of people of various ages - as people grow older, their expectations from work become more realistic $[13,15]$ and thus, easier to satisfy. The radio journalists took sick leaves significantly more often, and they had more days of absence caused by illness during the 12 months preceding the study. They assessed their health to be as good as that of other journalists' and therefore, their level of absence should be similar to that of other journalists. Here, the previous findings on negative relationships (although low) between job dissatisfaction and the absence from work seem appropriate [18-21]. It means that the radio journalists' absenteeism may have resulted from their lower job satisfaction. However, days of absence correlated with health assessment and perceived ability to work - no significant correlations between satisfaction and any job characteristic and absenteeism emerged in this group. Such a discrepancy may suggest that their absenteeism resulted from factors different than these studied here or it may follow the above-mentioned satisfaction being still relatively high in radio journalists in general. This would also explain the fact that the radio journalists were more involved in their work than other journalists. Previous findings suggest positive correlations between job satisfaction and job involvement [22,23]. In general, the radio journalists functioned better at work in comparison with other occupational groups. We compared the results of the radio journalists with general results of the whole population studied with the PRS, and it occurred 
that the radio journalists took fewer sick leaves, were absent from work twice less frequently, assessed their health, ability to work and work involvement better than the general population. Also, their turnover intention was weaker. Besides, they were also more satisfied with their work. Yet, only a slight difference was observed in the satisfaction with colleagues; both the radio journalists and the general population were highly satisfied with this aspect [8].

Although the studied respondents represented a high degree of occupational specialization, we confirmed the general relationships between stress and functioning at work that are typical for most professions. On the other hand, we found that even within the group of journalists there were significant differences between the representatives of various media. It means that some conclusions concerning stress and its consequences are universal and could be generalized to a larger population, and at the same time that researchers should remain sensitive to any slight differences between occupations.

The study, however, had its limitations. We were not able to find predictors of the psychosocial risk among the studied radio journalist because of the cross-sectional nature of the study. This limited the possibility to draw conclusions concerning causal relationships between the investigated phenomena. Longitudinal research would solve the above limitation. Job satisfaction, perceived ability to work or involvement could as well be results or antecedents of stress experience. Also self-report measures may not reflect the reality with such an exact precision as medical examinations of health or human resource department's data on employees' absence.

Moreover, we lacked information concerning specific domains of the radio journalists' work - whether they were broadcasting presenters, news researchers, copywriters; whether they had live programs or recorded them earlier etc. Such characteristics might have broadened our understanding of their functioning at work as well as any differences between them and other journalists.

\section{CONCLUSIONS}

Considering the above findings, it should be remembered that psychosocial risks and stress analysis should be based on the understanding of the specificity of each occupation or even position. Our study revealed differences between the journalists working for different media whose working conditions and environment may seem similar, but the perception of the job characteristics and their consequences may differ. Moreover, we believe that investigating occupational stress should encompass not only the very occurrence of potential psychosocial risks but also the subjective stress perception. The same job characteristic may pose a challenge for one person, while for another - it can result in extreme discomfort and anxiety. Such an attitude would broaden understanding of the phenomenon.

In the above study we also confirmed that the level of experienced stress influences employees' functioning. The job content, context and branch specific stressors, in general, differentiated functioning between the employees experiencing low and high levels of stress. As far as pathologies in relationships were considered (discrimination, violence, bullying, sexual harassment), no matter if they affected the employees themselves or their colleagues, neither did they result in differences in self-assessed health, job satisfaction, involvement nor turnover intentions.

Considering the fact, that all cases of pathological relationships were stressful to the employees, such results emphasize that other types of job demands - despite their potential to cause stress and negative health or functioning consequences - may be considered as inevitable characteristics of one's job. Pathologies in relationships, are always of abusive nature and therefore, must be reduced. Hence, the job content, context or branch specific stressors do not necessarily have to be eliminated - in some cases, coping skills may occur sufficient to prevent employees from negative consequences, while pathologies in relationships under no circumstances can be perceived as normal. First 
of all, such behaviors are against the law and, without exception, they are harmful and they debilitate functioning of an organization.

Also the common belief that job that involves providing entertainment is supposed to be pleasant, non-stressful and satisfactory cannot be supported. Although the radio journalists were satisfied and involved in their work, their satisfaction was significantly lower than that of other journalists. They also took more sick leaves and had more days of absence. Future research on causal relationships between the variables under the study would provide a verification of the antecedents of such functioning.

\section{REFERENCES}

1. [The Act of 29 December 1992 on radio and television. J Laws 1993, No. 7, item 34]. Polish.

2. Job offers for journalists [Internet]. Job offers browser [cited 2013 Jan 24]. Available from: www.jooble.com.pl.

3. [Ministry of Labour and Social Policy. Guide to professions]. Warszawa: The Ministry; 2003. Polish.

4. Trochimczuk M. [Indexes of audience ratings of radio programs in 2012]. Warszawa: Krajowa Rada Radiofonii i Telewizji, Departament Monitoringu; 2013. Polish.

5. International Labour Office. Psychosocial factors at work. Recognition and control. Geneva: The Office; 1984.

6. Leka S, Cox T, editors. PRIMA-EF: Guidance on the European Framework for Psychosocial Risk Management. A resource for employers and worker representatives. Geneva: World Health Organization; 2009.

7. Cox T, Cox S. Occupational-health: Control and monitoring of psychosocial and organizational hazards at work. Perspect Public Health. 1993;113(4):201-5, http://dx.doi. org/10.1177/146642409311300411.

8. Mościcka-Teske A, Potocka A. [Psychosocial Risks Scale. User manual]. Łódź-Gdańsk: Wydawnictwo NSZZ „Solidarność"; 2014, http://dx.doi.org/10.13140/2.1.3829.3129. Polish.

9. Väänänen A, Kalimo R, Toppinen-Tanner S, Mutanen P, Peiró JM, Kivimäki M, et al. Role clarity, fairness, and organizational climate as predictors of sickness absence. Scand J Public Health. 2004;32(6):426-34, http://dx.doi. org/10.1080/14034940410028136.

10. Chen MF, Lien GY, Lin CP. Modelling job stress as a mediating role in predicting turnover intention. Serv Ind J. 2011;31(8):1327-45, http://dx.doi.org/10.1080/0264 2060903437543.

11. Reineholm C, Gustavsson M, Ekberg K. Evaluation of job stress models for predicting health at work. Work. 2011;40(2):229-37.

12. Ertel M, Pech E, Ullsperger P, von dem Knesebeck O, Siegrist J. Adverse psychosocial working conditions and subjective health in freelance media workers. Work Stress. 2005;19(3):293-9, http://dx.doi.org/10. 1080/02678370500307289.

13. Hunt JW, Saul PN. The relationship of age, tenure, and job satisfaction in males and females. Acad Manage J. 1975;18(4):690-702, http://dx.doi.org/10.2307/255372.

14. Kumar BP, Giri VN. Effect of age and experience on job satisfaction and organizational commitment. ICFAI Univ J Organ Behav. 2009;8(1):28-36.

15. Gibson JL, Klein SM. Employee attitudes as a function of age and length of service - Reconceptualization. Acad Manage J. 1970;13(4):411-25, http://dx.doi.org/10.2307/254831.

16. Glisson C, Durick M. Predictors of job-satisfaction and organizational commitment in human-service organizations. Adm Sci Q. 1988;33(1):61-81, http://dx.doi.org/10.2307/ 2392855.

17. Rhodes SR. Age-related differences in work attitudes and behavior - A review and conceptual analysis. Psychol Bull. 1983;93(2):328-67, http://dx.doi.org/10.1037/0033-29 09.93.2.328.

18. Nicholson N, Brown CA, Chadwickjones JK. Absence from work and job satisfaction. J Appl Psychol. 1976;61(6):72837, http://dx.doi.org/10.1037//0021-9010.61.6.728.

19. Johns $\mathrm{G}$, editor. A multivariate study of absence from work. Acad Manag Proc. 1978;1:69-73, http://dx.doi.org/10.5465/ AMBPP.1978.4976495. 
20. Scott KD, Taylor GS. An examination of conflicting findings on the relationship between job-satisfaction and absenteeism - A meta-analysis. Acad Manag J. 1985;28(3):599-612, http://dx.doi.org/10.2307/256116.

21. Roelen CAM, Koopmans PC, Notenbomer A, Groothoff JW. Job satisfaction and short sickness absence due to the common cold. Work. 2011;39(3):305-13, http://dx.doi. org/10.3233/WOR-2011-1178.
22. Cheloha RS, Farr JL. Absenteeism, job involvement, and job-satisfaction in an organizational setting. J Appl Psychol. 1980;65(4):467-73, http://dx.doi.org/10.1037//0021-9010. 65.4.467.

23. Wegge J, Schmidt K-H, Parkes C, van Dick R. Taking a sickie: Job satisfaction and job involvement as interactive predictors of absenteeism in a public organization. J Occup Organ Psychol. 2007;80:77-89, http://dx.doi.org/10.1348/096317906X99371.

Project co-financed by the European Union in the framework of the European Social Fund

This work is available in Open Access model and licensed under a Creative Commons Attribution-NonCommercial 3.0 Poland License - http://creativecommons.org/ licenses/by-nc/3.0/pl/deed.en. 